\title{
THE WAYANG STORY IN MODERN INDONESIAN FICTIONS (Reviews on Mangunwijaya and Sindhunata's Novels)
}

\author{
Burhan Nurgiyantoro \\ Universitas Negeri Yogyakarta \\ email: burhan@uny.ac.id
}

\begin{abstract}
The wayang is a traditional story which influences toward the writing of modern Indonesian literature. This study is aimed at describing the adoption of aspects of stories in the wayang plays in modern Indonesian novels with a focus on Mangunwijaya and Sindhunata's novels; i.e. Burung-burung Manyar, Durga Umayi, and Anak Bajang Menggiring Angin. The study uses the receptional, intertextual, and discourse-analysis approaches. Results show the following findings. Character referencing from shadow-wayang stories includes naming and characterizing, viz. complete adoption of names and characters of wayang figures, hypogram of simultaneous naming and characterizing, and characterizing with no naming. The hypogramming of novel plots on the shadow puppet plots includes shadow-puppet show plots and shadow-puppet story plots. Every work has its own uniqueness and it is on this uniqueness that lies the values of a fiction work. This can be seen from the development of characterization of the figures and specific and unique plots. The value substances of the wayang story are related to personal, social, and religious life matters leading to perfect lives. Shadow-wayang values in novels are discharged through signification, comparison, symbolization, characters, life principles, and behaviours functioning more as cultural guidances.
\end{abstract}

Keywords: shadow wayang, modern Indonesian novels, hypogram, characterization, plot, values

\section{WAYANG DALAM NOVEL INDONESIA MODERN (Tinjauan Novel Mangunwijaya dan Sindhunata)}

\begin{abstract}
Cerita wayang adalah adalah cerita tradisional yang berpengaruh terhadap penulisan sastra Indonesia modern. Penelitian ini bertujuan untuk mendeskripsikan pemunculan aspek cerita wayang dalam novel Indonesia modern dengan fokus pada novel Mangunwijaya dan Sindhunata, yaitu Burung-burung Manyar, Durga Umayi, dan Anak Bajang Menggiring Angin. Penelitian menggunakan pendekatan resepsi, intertekstual, dan analisis wacana. Hasil penelitian menunjukkan hal-hal sebagai berikut. Perujukan penokohan dari cerita wayang mencakup penamaan dan perwatakan, yaitu pengambilan lengkap nama dan karakter tokoh wayang, hipogram penamaan dengan perwatakan sekaligus, dan perwatakan tanpa disertai penamaan. Hipogram plot novel pada plot wayang men-
\end{abstract}


cakup plot pertunjukan wayang dan plot cerita wayang. Tiap karya memiliki keunikannya sendiri dan di situlah antara lain letak nilai sebuah karya fiksi. Hal itu terlihat pada pengembangan karakter tokoh, plot yang khas dan unik. Substansi nilai-nilai cerita wayang berkaitan dengan masalah kehidupan pribadi,sosial, dan religiusyang bermuara untuk mencapai kesempurnaan hidup. Nilai-nilai wayang dalam novel disampaikan lewat pembandingan, pelambangan, simbolisasi, karakter, sikap hidup, dan perilaku tokoh yang lebih berfungsi sebagai acuan kultural.

Kata Kunci: wayang, novel Indonesia modern, hipogram, penokohan, plot, nilai-nilai

\section{INTRODUCTION}

Up to the present time, the wayang story is widely known in the Javanese society, also Indonesian society, especially the one that is presented through the shadow-wayang show. Shadow wayang story books, both in the prose and poetry genres, both leather wayangs and wayang theatres, all originate from shadow wayang stories. The wayang stories are epics originating from the genres Mahabarata and Ramayana. In core, the two genres narrate the heroism of protagonistic characters to face and destroy antagonistic characters. Looking at its long history and the fact that many people still like it, it shows the high value and meaning of shadow wayang in the life of the society. From the point of view of the present era, shadow-wayang stories can be seen as fulfilling the criteria of masterpieces, highly valued literary and cultural works. In addition, it can be used as a 'brigde' which connects old and modern cultures since it is seen as a gap between both cultures (Rochmat, 2018).

The original texts of the wayang stories, both of the genres Mahabarata and Ramayana, are not of Javanese literary origins. Both originate from India and are written in Sanskrit. Upon coming in- to Java, the texts are translated and edited into Old Javanese. The translation and edition, doubled by the adoption of stories and legends living in the society, produce Mahabarata and Ramayana of the Javanese version (Groenendael, 1985). Shadow-wayang stories living in the society presently are cultural heritages of an old age dating not less than 3,500 years ago (Mulyono,1989:1). The texts and stories of the wayang of the Javanese version has been continuously rewritten, edited, and added with various stories of the later time, and now are even written in Indonesian and foreign languages.

The importance of the influence of waang onto the Javanese society in the past time can also be seen from temple reliefs depicting wayang figure and stories. For example, through anthropological studies the figure of Bima (the second of the five Pandawa brothers) can be seen as reliefs in Sukuh Temple, Karanganyar (Middle Java) and Penanggungan Temple. In other temples, reliefs can also be seen of Ramayana stories such as in Loro Jonggrang Temple in Prambanan (Yogyakarta) and Panataran Temple in Blitar (East Java); reliefs that tell about the Arjunawiwaha shadow-wayang story can be 
seen in Jago Temple, Surawana Temple, and Kedaton Temple (Kasnowihardjo, 2012: 3). It must be remembered, however, that shadow-wayang cultures are also found in other countries such as Malaysia, Thailand, and surely India as their place of origin.

The wayang stories are not only of the Javanese ethnicity; it is also the treasure of other Indonesian ethnics (such as Balinese and Sundanese), and is even the belonging of the Indonesian nation. Now, the wayang culturees are acknowledged as valued international heritages. In 1997, UNESCO, the UNO affiliated organization in education, science, and culture, developed the laws for Masterpiece of Oral and Intangible Heritage of $\mathrm{Hu}$ manity. Through accurate research, on 2003, in Paris, the Indonesian wayang sories or culture was declared by the UNESCO as Masterpiece of Oral and Intangible Heritage of Humanity of the world (Wibisana 2009; Kasnowihardjo 2012: 3; Sudjarwo 2010: xxxiv). ${ }^{1}$ This again shows that the wayang stories are acknowledged as a value-loaded international cultural heritage that has a great role in the forming and developing of nation identities. It is therefore natural that the the wayang becomes a source of reference for the writing of literary works in modern Indo-

1) There are five kinds of wayangs were included, namely (i) old Javanese wayang from Middle Java, (ii) old Balinese wayang from Bali, (iii) Sundanese doll wayang from West Java, (iv) Palembang wayang from South Sumatra, and (v) Banjar wayang from South Kalimantan (see Wibisono, 2009; Sudjarwo et al, 2010; Kasnowihardjo, 2012). nesia. The monumental and valuable work can be seen as the canonical literary work (Thomsen, 2017:4). Thus, the wayang story is the classic literary work which is monumental and valuable as the canonical literature to the traditional literature.

The wayang is also widely read, studied, learned, and taken as research material in various countries in the world, including shadow-wayang stories contained in literary works. Such has been done, for example, by Figueras-Lucero (1997) who investigated the aspects of shadow wayang in the Pramudya's novel Perburuan; Downes (2012) who studied such aspects in Y.B. Mangunwijaya, Putu Wijaya, dan Ayu Utami's modern Indonesian novel; Mustikasari et.al (2012) researched the same aspects in Yanusa Nugroho's Di Batas Angin karya; Varela (2014) who studied about innovations in the contemporary Javanese shadow wayang in her dissertation; and Foley (2005) who researched shadow wayang performances as media for studying Indonesian cultures by students in California. In addition, the present study is similar with O'Neill (2017:65-75) who studied the transformations of the "Transformative Tales for Recessionary Times: Emma Donoghue's Room and Marian Keyes' The Brightest Star in the Sky". The writing of these two works and two writers has much influence or intertextualization from references to Victorian fairytale.

Facts show that quite many of modern Indonesian literary works use, refer to, reveal hypogram, or reactualize shadow-wayang stories. Writers like Y.B. Mangunwijaya, Sindhunata, Putu Wijaya, Sena Gumira Adjidarma, Yanusa 
Nugroho, Tjahyono Wibisono, Amrih Pitoyo, and others bring up shadow-wayang stories as one of their inspirations and sources. Notwithstanding, there are differences in the way they "treat" the wayang stories in their works. They may even use their own ways in telling about the wayang stories such as those in $\mathrm{Wi}$ sanggeni and Drupadi (Sena Gumira Adjidarma), Anak Bajang Menggiring Angin (Sindhunata), Hanoman, Akhir Bisu Sebuah Perang Besar, The Darkness of Gatotkaca, and Sebuah Novel Pahlawan Kesunyian (Pitoyo Amrih).

The theories underlining this study are related to reception of literary aesthetics and intertexts. The receptional theory deals with the reception of or responses to literary texts by readers. A reader's reception on a literary work is subjective in nature, determined by the perception, literary experience, and depth of the reader's impression on the work. A single literary work may impact different responses by different readers. This theory is first put up by Iser (Habib, 2005: 724) who states that there are two patterns in reception, namely the "artistic" pole in which the text is created by the author and the "aesthetic" pole in which the realization is acomplished by the reader. The two poles must be there and run simultaneously. Iser's receptional theory requires the active role from the part of the reader.

Literary works can emerge from a society that already possesses the convention, tradition, aesthetic views, literary goals, and others that can be seen as cultural realizations. This means that, in fact, literature is a social convention because the society wants it. Concrete reali- zation of the cultural convention can be the works that have been produced by people in the past, including folklores given down orally from generation to generation, which later are referred to as mythology. The intertext theory views that later texts are written based on the existing texts. A text commonly uses a previous text as an example, guide, framework, reference, or model. This will also bring out consequences on the part of the readers.

Modern Indonesian literary works which reactualize shadow-wayang stories can be seen as using the stories as their bases. In the intertext concept, this can be called as a hypogram (Riffaterre, 1980:23). Hypograms are previous works, traditions, and conventions that are viewed as challenges to be responded to and bases for later works. It is no wonder that there are various transformational forms of wayang stories in modern Indonesian literary works notwithstanding that they are based on the same Mahabarata and Ramayana epics. The resulting literary works can be regarded as new works. The references from other works, which may be in the forms of conventions, certain formal forms, or ideas, can still be recognized.

The present study limits its scope on three novels by two famous writers, Mangunwijaya (6 May 1929 - 10 February 1999) and Sindhunata (12 Mey 1952). These writers are intentionally taken for their similarities in that both are priests, have interests in traditional wayang stories, and are productive writers. Their interests in the wayang stories are revealed in their creative novels; although not all their novels contain wayang story ele- 
ments. In addition, both are graduates from German universities; Mangunwijaya majored in architecture, Sindhunata is a doctor in philosophy. In addition, the study is also limited to the inclusion of wayang stories in the forms of characterization, plot, and the prominent values. The study is focused on how the two writers reveal and respond to various wayang aspects in their novels.

The study is aimed at describing various forms of hypograms including characterization, plot and values in the novels Burung-burung Manyar, Durga Umayi, and Anak Bajang Menggiring Angin which are the products of the writers' creativities and responses.

\section{METHOD}

The study focuses on the novels of Mangunwijaya dan Sindhunata. Both are productive writers with many novels, but the novels taken are the ones intensively reactualizing wayang stories. For Mangunwijaya, two novels are taken; for Sindhunata, one novel is taken. Mangunwijaya's novels are Burung-burung Manyar (first printed 1981) dan Durga Umayi (first printed 1991), and for Sindhunata, the novel is Anak Bajang Menggiring Angin (first printed 1983). In the three novels, hypograms of wayang stories can intensively be seen; wayang stories that become cultural references, figures, characters, plots, values, and even sources of writing, but are presented and created using the writing styles of modern novels.

The study adopts the receptional and intertextual approaches and uses textanalysis techniques. The three novels are compared to wayang stories in figures, characters, plots, values, and others that are related. The primary text-analysis tool is knowledge of the world; i.e. the researcher's knowledge of the world and of wayang stories. These aspects of knowledge are parts of the researcher and, therefore, the research instrument is the researcher himself.

In addition, data for the wayang stories refer to various books about wayang stories such as Rupa \& Karakter Wayang Purwa (Heru S. Sudjarwo, Sumari, and Undung Wiyono, 2010), Ensiklopedi Wayang (Djoko Dwiyanto, Sukatmi Susantika, Wiwien Widyawati, 2010), Ensiklopedi Tokoh-tokoh Wayang dan Silsilahnya (Mahendra Sucipto, 2010), Silsilah Wayang Purwa Mawa Carita, volumes I-VII (S. Padmosoekotjo, 1992), Ensiklopedi Wayang Purwa (Suwandono, Dhaniswara, dan Mujiyono. 1993), Mahabharata (C. Rajagopalachari, 2008), Mahabrata (P. Lal, 1992), and Ramayana (P. Lal, 1995). Data analysis is done by the descriptive qualitative technique by describing the hypogram forms of wayang stories in the three novels especially in the aspects of characterization, plot, and values.

\section{RESULTS AND DISCUSSION Results}

The use of wayang story aspects in the three novels of Burung-burung Manyar, Durga Umayi, and Anak Bajang Menggiring Angin related to characterization, plot, and values can be summarized as follows.

Burung-burung Manyar. Characterization of the novel contains hypograms from the names and characters of wayang figures. Figures like Setadewa, Larasati, Antana, Janakatamsi, and Brajabasuki are ones that are transformed 
from names of wayang figures. For the main characters of the story, Setadewa is a hypogram of the wayang Kakrasana or Baladewa (Kakrasana's name in old age) and Larasati is a hypogram of the same name in the wayang stories. The plot of the novel is a hypogram of the plots in the wayang stories (there are many wayang stories, either pakem or carangan $)^{2}$. There are many values coming from the wayang stories. One value contained in the novel is the struggle in erecting truths and taking up responsibilities. These two aspects are core values of all wayang stories. The novel tells about modern life and characters, however, with wayang performance and story patterns; so that it later is referred to as a wayang novel.

Durga Umayi. Durga and Umayi are names of wayang figures. Durga is a goddess with an ugly face and evil characters while Umayi, wife of Batara Guru, king of the gods, is a goddess with nobel characters. The main character of the novel is Iin Sulinda Pertiwi, a girl with split personalities, a hypogram of the the two goddesses in the wayang stories. This can be seen from the "pre-wayang" (a kind of preface to the novel) telling about Durga and Umayi in the wayang stories. Parts of the plot of the novel have a hypogram to the plot in the wayang stories; even the sub-chapters have the pictures of certain wayang figures. The name Pertiwi simultaneously indicates that Iin symbolizes the

2) Pakem: Origin of stories, standard stories. Carangan: development, extension, or recreation of stories suited to needs and contexts, but in similar lines with the standard version in plots, character patterns, and parts of the story.
Indonesian nation. One of the many values in the novel refers to the heroic struggle and awareness to return to the truths actualized by values in the wayang stories. From the intensiveness of the referencing to the wayang stories and the styles that are similar to the wayang player's, the novel can be considered as a wayang novel.

Anak Bajang Menggiring Angin. The novel fully tells about stories based on the standard Ramayana; this novel can then be considered as a wayang novel. Seen from the plot, the figures, in names, characters, and values are hypograms of and actualized by wayang stories. However, all are narrated in the novel style. The main character of the novel is Anoman, a major figure in wayang stories. Anoman's five brothers, who are not main characters in wayang stories: Kilatmeja, Ramadaya, Dayapati, Garba Ludira, and Pulasio become important figures in the novel and even become the symbolization of the title of the story. They are narrated as young spirits, baby ghosts, not yet reaching the perfect forms of humans, who then transmerge into the self of Anoman to help him fight against Rahwana. The plot is built up chronologically presenting various stories using specific and unique styles by the writer. The novel recreates the Ramayana stories using the novel style; therefore, it can be considered as a wayang novel. Also there are many values coming from this wayang novel. The values of three novels, in substance, wayang values are related to personal, social, and religious matters in the efforts to reach perfect life.

The hypogramming of wayang story aspects in the three novels related to characterization, plot, and values can be summarized at Table 1. 
Table 1: The Hypogramming of Wayang Story Aspects in the Three Novels

\begin{tabular}{|c|c|c|c|}
\hline & The Novel & Hypogramming & $\mathrm{Ad}$ \\
\hline & Burung-burung Manyar & Characterization & - Names of wayang figures \\
\hline & & & - Characters of wayang figures \\
\hline & & Plot & - Wayang stories \\
\hline & & & - Wayang shows \\
\hline & & Values & $\begin{array}{l}\text { Related to: personal, social, religious } \\
\text { matters in the efforts to reach perfect } \\
\text { life }\end{array}$ \\
\hline & Durga Umayi & Characterization & - Names of wayang figures \\
\hline & & & - Characters of wayang figures \\
\hline & & Plot & Wayang stories \\
\hline & & Values & $\begin{array}{l}\text { Related to: personal, social, religious } \\
\text { matters in the efforts to reach perfect } \\
\text { life }\end{array}$ \\
\hline \multirow[t]{3}{*}{3.} & Anak Bajang Menggiring Angin & Characterization & $\begin{array}{l}\text { - Names of wayang figures } \\
\text { - Characters of wayang figures }\end{array}$ \\
\hline & & Plot & Wayang stories \\
\hline & & Values & $\begin{array}{l}\text { Related to: personal, social, religious } \\
\text { matters in the efforts to reach perfect } \\
\text { life }\end{array}$ \\
\hline
\end{tabular}

\section{Discussion}

Elements of wayang stories of the three novels described below presented in the aspects of characterization, plot, and values.

Characterization. Seen from the aspect of characterization, hypogramming of the characterization from the wayang stories includes two matters: naming and characterizing. Variation in the hypogram models can be seen in the complete adoption of the names and characters, simultaneous naming and characterizing, and characterizing with no naming.

Name and Character Hypograms. Hypogramming of names and characters can be seen in Anak Bajang Menggiring Angin and Burung-burung Manyar. In Durga Umayi, names in the novel are not hypograms of names in the wayang stories, although the pre-wayang section tells about the wayang story. nama tokoh ti- dak berhipogram pada nama tokoh-tokoh wayang walau pada 'Prawayang' menghadirkan cerita wayang.

All figures in Anak Bajang Menggiring Angin completely refer to the wayang figures, both in names and characters. Figures in the novel such as Rama Wijaya, Laksmana, Begawan Wisrawa, Dewi Sukesi, Anjani, Hanoman, and Rahwana are figures in the standard Ramayana. Anak Bajang Menggiring Angin is a Ramayana story told by the writer in his own way and style just like one in a fiction novel.

In a similar case, figures in Burungburung Manyar like Setadewa, Larasati, Janakatamsi, Brajabasuki, and Antana are hypograms to wayang figures. Seen from the intensiveness of the hypogramming, the two figures of Setadewa and Larasati much more have reference to 
wayang stories than do Janakatamsi, Brajabasuki, and Antana. This is because the former are main characters and the latter peripheral. The name Setadewa is hypogrammed to Baladewa (name of Kakrasana after crowned King of Madura), by taking the word "dewa", while "Seta" is one of Baladewa's characters. "Seta" means 'white' as Baladewa has white skin (Baladewa is the reincarnation of God Basuki who has white skin); honest, and free from sins. The name Setadewa then is a cluster of "Seta" and "Dewa"; "Dewa" is a name, while "Seta" is a character.

Besides hypogramming to names, the figure Setadewa is hypogrammed to many characters of Baladewa. This hypogramming includes behavioral, mental, and physical characteristics. Setadewa has White skin and, therefore, in his childhood, he is called by the name of Raden Mas Sinyo (nickname for children with white skin). This is a transformation of the physical characteristic of Kakrasana. As a young man, Setadewa temperamental and has uncontrolled emotion; but he is also faithful to promises, loves only one woman, is independent, has no begging mentality, is honest, does not hide evils, does not want to devote to facists and robbers, and remains to love Indonesia although he works for a foreign company. These are mental and behavioral attitudes owned by Kakrasana and Baladewa who can get angry easily and are temperamental, but forgiving and thoughtful (Sudjarwo et al., 2010: 512). In his mid age, Setadewa grows more mature, calm, and able to control his emotions. Setadewa's characters develop and are depicted from many sides and, there- fore, he is a round character. On the other side, Baladewa has a more settled character pattern, just like other wayang figures who have flat characters.

Setadewa's principles in being faithful to Indonesia, besides hypogramming to Baladewa, also to Karna dan Salya. The wayang story: Baladewa, Karna, dan Salya (father-in-law of Karna), are in the side of Kurawa, but their attachment to never fades. Karna dan Salya even are willing to die in the Baratayuda battle for the victory of Pandawa who is given the responsibility by the god to eradicate evils (Sudjarwo, et al., 2010). The novel: Setadewa is willing to sacrifice himself to be fired from the multinational oil company for his love of Indonesia. He knows that the oil company is fraud and inflicts losses to Indonesia. He cannot accept that his country (he firstly hated) is cheated and robbed by a foreign body. This attitude is a hypogram to Karna dan Salya dalam in a different way which is contextual.

The wayang: Baladewa is a reincarnation of Laksmana (a major figure in standard Ramayana) who chooses to be unmarried for his oath to Sita. After becoming a monk, he does not pay attention to women. The novel: This condition is transformed to Setadewa puts more concern to his career than to his wife such that his marriage to an American woman goes ashtray. He also refuses to accept the persuasion of Mrs. Antana (mother of Larasati) to "take" Larasati. The wayang: after the Baratayuda battle, Baladewa takes care of Pandawa's descendent, Parikesit, to be King of Astina. The wayang: is transformed to Setadewa in his willingness to take care of the three chil- 
dren of Larasati after they become orphans. Larasati and her husband, Janakatamsi, are killed in a Haj airplane crash in Ceylon on their way to the Holy Land.

For the figure Larasati, the name is a hypogram of Larasati in the wayang, grand-daughter of Antagopa. In the novel, Larasati is daughter of Antana. The name "Antana" is a hypogram of "Antagopa". Besides figure hypogramming, there are also hypograms in family relations, father-and-child relation. There is a parallel in the father-child relation between Antagopa and Larasati in the wayang story and Antana and Larasari in the novel.

The same parallelism occurs in the relations between Setadewa and Brajabasuki and Baladewa and Basudewa. Baladewa is son of Basudewa; the name Brajabasuki is a hypogram to Basudewa. The occurence of these family relation equivalences adds to the occurence of transformation of wayang stories to the characterization in the novel Burung-burung Manyar.

The figure Larasati in the novel also seems to be a hypogram to the wayang figure Sri Kandi physically, behaviorally, and mentally. The posture showing beauty, the lively movement, the heroic spirit, the leadership, the willingness to do anything for the man she loves are characteritic of both Larasati and Sri Kandi (see Sudjarwo et al., 2010; Sucipto, 2010; Padmosoekotjo, 1992). Larasati is one of the Indonesian heroines for independence. Women figures in great struggles are referred to or symbolized as Sri Kandithe female knight in the wayang stories.

The phenomena that many modern
Indonesian literary works use hypograms from wayang stories, especially in the characters, as stated by Kuntowijaya (1984: 128-9) long before, show that characterization in many modern Indonesian novels has the typologism traditions. This fact indicates that the wayang traditions are still strongly rooted in the Javanase society and in modern Indonesian literature. This seems to be related to the socio-cultural backgrounds of the writers (Mangunwijata and Sindhunata are of Middle Java origin where the wayang traditions are still strong) that become the pre-conditions for the creation of literary works. As heirs of the collective cultures, writers have the obligation to choose media that are known to the public. The adoption of wayang stories will shorten narration, on the one hand, and speed up comprehension, on the other; and it is thus more efficient. The transmission of message through the literary work is more communicative and, in turn, more comprehensible.

Hypogram of Character with no Name. The main character in the novel Durga Umayi is Iin Sulinda Pertiwi (later on: Iin), while the other charaters are peripheral. Seen from the case of naming, there seems to be no hypogramming to wayang figures. However, seen from the case of characterizing, Iin is a hypogram to Durga and Umayi. She is described as a woman with split personalities: sometimes nobel and sometimes evil. The two spliting personalities of good and bad are hypograms to or symbolized by the two wayang figures: Umayi, who is a goddess with beauty and a good heart, and Durga, who is a goddess with an ugly face and an evil heart. The symbolization of 
this split personality even becomes the title of the novel.

Seen from the physical side, Iin, who has fair skin, beautiful face, and sexy body depicts the posture of Dewi Umayi who has perfect beauty. In her maiden age, Iin is a girl with good characters, likes to help others, and is a figure in the independence struggle. These good characters are hypogramming to the characters of Dewi Umayi. On another side, Iin's involvement in the battle front of the independence revolution with his father is a hypogram to the wayang figure Sri Kandi, who is a female knight beside her husband, Arjuna. So, Iin's good characters are symbolized in and hypogrammed to the two wayang figures Dewi Umayi and Sri Kandi.

In the development, in her involvement in the independence struggle, Iin kills enemy soldiers, is captured, and is raped by a NEFIS member. Feeling that she is no longer pure, because of the rape, after the war, she plunges into the black world: becoming a high-class prostitute, changing partners, living together without marriage ties, and becoming an international lobbyist, legal or illegal, relying on her physical charms. She is able to accumulate wealth and later becomes a wealthy conglomerate. These characters of Iin, allowing all ways to gain wealth, are hypograms to Durga who is imaged as a figure who has evil characters.

One of the tourism megaprojects located in an outmost village in Middle Java runs over the land belonging to her twin-brother, Brojol, who is a poor farmer. This raises Iin's conscience. She wants back to become Umayi to cancel the project and return the lands to the people. She wants to redeem her wrongs. But, she is faced with a dilemma since the state government demands that the project be continued to avoid shame from the international world. And so, Iin is again fettered by the two choices: Umayi or Durga! Characters of the wayang figure are symbolizations, symbolizations of a person who has split personalities. In fact, the core problems of man are the same all the time. The difference lies in their manifestations in life according to the era. Manifestations of these two characters also occur in life of this supermodern world. This shows that the Javanese local culture is now elevated to become an Indonesian (Mustikasari, 2012) as it is brought up in modern Indonsian novels.

In another aspect, the word "Pertiwi" in the complete name Iin Sulinda Pertiwi can be connotated as "pertiwi" meaning 'motherland'. In a wider sense, Iin symbolizes the Indonesian fatherland, Indonesian country. Iin's life symbolizes the life of the Indonesian nation. Iin's life stream is narrated through the traditional life, involvement in the war, being raped, becoming a high-class prostitute, becoming a high-class, accumulation of wealth, becoming a conglomerate, and finally returning to the right way as Umayi in spite of the ambivalence to stay as Durga. This is in line with the way of life of the Indonesian nation who is "trapped" in the two choices of good and bad matters (see also Downes, 2012:144). In the life of a person, or a nation, there are always choices each of which carries its consequences.

Ftrom the literary views, Iin's characters develop and is narrated through the various sides of her life so that she beco- 
mes a complex character in the novel, more complex than the wayang characters in the wayang stories being hypogrammed. This adds to the literary value of the novel.

Plot. Of the plot, the novel plot that is a hypogram of the wayang plot can be differentiated into two kinds: wayang story plots (there are many wayang stories) and wayang show plots (leather puppet). Plot hypogramming to wayang shows can only be found in Burung-burung Manyar, while plot hypogramming to wayang stories can be found in all the three novels.

Wayang Show Plot. Seen from the time reference, the novel Burung-burung Manyar is divided into three parts. Novel: Part one (1934-1944) tells about the childhood time of Setadewa dan Larasati. During the Japanese occupation, Setadewa's father is threatened by Kenpeitai, and so Setadewa is given to the family of Antana, Larasati's father di Jakarta. Part two (1945-1950) narrates the youth life of Setadewa dan Larasati. Setadewa sides with the Dutch by becoming a KNIL soldier because of his hatred towards the Japanese for harming his father and mother. Larasata sides with the Republic. After the defeat of the Dutch, Setadewa confesses his mistakes, goes to study overseas, and long disappears from the scene. Part three (1968-1978) tells about the re-encounter between Setadewa Larasati. Larasati is now married to Janakatamsi and had three children. After Larasati and anakatamsi are killed in the Haj plane crash, Setadewa takes care of the three children.

Wayang show: the plot pattern in wayang shows consists of three parts; each is marked by a stereotypical event and is accompanied by a different music piece. From the division of the hours, the first part of the show runs between 21.00 and 24.00 hours, the second between 24.00 and 03.00 hours; and the third between 03.00 and 5.00 hours. This pattern is a symbolism of the life phase of human beings; childhood, youth, and old age, (Sutriso, 2010:7-8) that tend to have different characteristics. In the novel, the symbolization of the life of man through the plot in the wayang show is concretely hypogrammed in the life of the two main characters into intervals of years describing their childhood, youth, and old age. This is done intentionally. It seems that the writer intentionally inserts the story, pattern, philosophy, characters, and values of the wayang show into the novel; or he narrates the life paths of modern persons using the patterns of the wayang show. The first thing he does is taking up the characters, philosophy, and values of the wayang into the novel; and second thing is hypogramming the plot of the novel to the plot of the wayang show. It can be seen, therefore, that the novel plot adapts the wayang plot and it can be said, therefore, that the novel is a wayang novel. Furthermore, as it is true with art works, wayang shows in the present time involve aesthetic and thematic explorations and innovations (see Varela, 2014).

Wayang-story Plot. There exist a lot of wayang stories, coupled by the emergence of new stories. Wayang-story plots are those that can be found in wayang stories. In Burung-burung Manyar, the plot of Setadewa's life is a hypogram to the plot of Kakrasana (Baladewa). This is 
evident from the hypogramming of the name and characters of the figure Kakrasana.

The plot hypogramming aspect can be summarized as follows. (1) Wayang: together with his younger brother and sister (Narayana and Dewi Lara Ireng), Kakrasana is sent to Widara Kandang, in Antagopa's house, father of Larasati, because of the presense of threat from Kangsa. Novel: Setadewa is sent to the house of Antana, father of Larasati, because of the threat from the Japanese towards his father for his being a Dutch soldier. (2) Wayang: for a personal reason, viz. being in oaths to the wife and King of Astina, Kakrasana sides with Kurawa, while Larasati with Pandawa. Novel: Setadewa, also for a personal reason (Ono, the Japanese Kenpetai commandant ruins his mother and kills his father), sides with the Dutch; Larasati, secretary of thge Primer Minister Syahrir, sides with the Republic. (3) Wayang: After the Baratayuda War, Kakrasana takes care of Parikesit, heir of Pandawa, i.e. son of Abimanyu and grandson of Arjuna, because his love to Pandawa never fades. Novel: After Larasati and her husband's death, Setadewa takes care of the three children of Larasati for his love to Larasati that also never fades.

Wayang: another hypogram to the convention of wayang stories is related to the life story of Baladewa who is the reincarnation of Laksmana. Because Laksmana is celibate, Baladewa follows. But this happens after he is married to Dewi Erawati. Novel: This condition is hypogrammed to the marriage failure of Setadewa to an American because of career. After this failure, Setadewa is deter- mined to stay unmarried.

On another side, there are hypograms that ignore conventions. Wayang: Larasati loves Kakrasana but as a brother. She is married to Janaka. Novel: Larasati is in deep love with Setadewa such that she is going to propose to him. In her re-encounter with him, after years of separation, Larasati, who is married and has three children, still loves Setadewa. This is not the same with what happens in the wayang stories.

Plot hypogramming also occurs in Durga Umayi. The novel presents a prewayang (preface to a text) that tells about the lives of Durga and Umayi. The prewayang gives an indication that the novel that will be presented has a connection with the life stories of the two wayang characters. In fact, it is the story and characters of these two wayang figures that are mainly hypogrammed to the life story and characters of Iin.

The beautiful Iin is hypogrammed to Dewi Umayi by doing various good deeds including going to the battle field to fight against the colonizers. But, after slaughtering a dying Gurka soldier, she feels cursed by Batara Guru so that she has the characters of the evil Batari Durga. Thus, she undertakes occupations regarded as improper such as being a prostitute, using her physical advantage to be a lobbyist, allowing all ways to accumulate wealth. Iin's life path is circled to a dilectical position, there being a conflict between the legal and illegal, between the good and the bad, and between sticking to the glamorous modern life and coming back to traditional life that has become her cultural root. All this is symbolized in the characters of Dewi Umayi and Batari 
Durga. The hypogram of wayang stories to Iin's life stories is symbolistic. This can also be seen from the subtitles of the novel that are given the pictures of certain wayang figures. So, in fact, Iin's life streams are not only hypogrammed to Durga and Umayi, but also to other wayang figures such as Sri Kandi (female patriot), Sarpakenaka (female sexual pursuer), Togog (materialistic servant), and others that are used as subtitles in the novel.

In addition, seen from the narrating style, the novel Durga Umayi is narrated in a specific way, different from the common, that is by the narrating technique used by a wayang player. In the shadow wayang performance, the wayang player narrates the story continuously, by himself, using formal and nonformal language styles, seriously but humorously all at once asking the viewers to laugh. So is the narrating style of the novel; flowing continuously in long paragraphs, mixing among narration, dialogues, comments, critiques, praises, and so on. However, because it is narrated using the wayang player's style, this means that the novel tells about wayang stories. The wayang is a symbolization of man's life. Iin is therefore there to symbolize the life of man or, even, the life of the Indonesian nation (see Downes, 2012: 134-135).

This is different from the novel Anak Bajang Menggiring Angin. The novel is sourced from wayang stories (Ramayana) written in a novel style. In the great outline, the story reflects the standard wayang story. But, how the events are sequenced, thus the plot, is developed through the acceptance, attitudes, beliefs, and styles of the writer including the ad- dition of scenes and dialogues that are intentionally done creatively. It is a fact that there are no two works that are the same although they are taken from the same source. It is here that the writer's creativity lies. Every work has and shows its own specific characteristic and uniqueness, and this is where the value of a fiction work lies. These phenomena can be seen in the development of the figures' characters, the plot, that is all specific and unique. It is therefore true that the novel can be regarded as a wayang novel.

Values. One of a writer's motifs in writing a novel is to present humanistic values. The purpose of the wayang stories is the same since a wayang story is both an entertainment and an enlightment (Sutrisno, 2010:6). Wayang stories also tell about humans and humanities, life and living. In substance, humanistic values do not change from time to time; it is the manifestation in the real life that is contextual. Wayang-story values cover various aspects of the human life. They can be differentiated into personal, social, and religious lives. These values function to support the efforts to continue, maintain, and develop life leading to the goal achievement of perfect life. Literary work which contains good values are taught at once to support the purpose of character education (Irwansyah, Nurgiyantoro, \& Sugirin, 2019).

In general, wayang values in literary texts are presented through comparison, symbolization, characters, life attitudes, and behaviours of the characters that are related directly or indirectly to the wayang figures. Thus, in this case, wayang values function more as cultural references. Wayang stories are symbolistic 
works that put emphasis on the importance of the core problems that are being symbolized. The core problems that are in the forms of wayang philosophies and values are packaged and actualized through the writing of novels in the modern life backgrounds. Mangunwijaya dan Sindhunata believe that wayang stories are high cultures that have high values and that are still relevant to today's life. The two writers therefore intentionally choose and recover wayang values in their fiction works.

The values are related to personal matters not only of feelings such as love, sexual drive and intercourse, faithfulness to husband; but feelings of ambivalences such as split personalities, devotion attitudes, unwillingness to support family members who do wrong, and others. In the case of sexual intercourse, for example, if the activity is done mainly to fulfill sexual desires, it will give poor off springs. The wayang figure Batara Kala, a maneating giant, is born of the uncontrolled sexual desire of Batara Guru (Durga Umayi); the wayang figures Rahwana, an evil King, and Sarpakenaka (a sex-pursuer female) are also born of the sexual desires of Begawan Wisrawa and Dewi Sukesi (Anak Bajang Menggiring Angin). Later on, when the sexual intercourse between Wisrawa and Sukesi is not only driven by sexual desires, but also accompanied by prayers to god, the born baby, Gunawan Wibisana, becomes a person with good characters, religious, and defender of truths.

When Iin (Durga Umayi) is faced with the choice between cancelling the project and returning the land to the people, she contemplates. She is decided to return to herself before she is coopted with bad behaviours and to come back to his only brother. She is decided to leave off the evil Durga characters and to return to become the good Umayi. The novel intentionally does not present a solution for Iin's choice since it is abruptly ended. This here lies the role of the readers to fill up the gap in line with their expected horizons, a view from Iser's reception theory (Habib, 2005)). The story "merely" presents two choices to Iin, both are equally hard: Durga or Umayi. But, Iin is old, a time to repent; therefore where the choice is to go is predictable.

She intends to buy back all the village land ricefields and everything else that have been bought by the project, meaning all the 1945 hectares of land that has been demolished flattened by trucks she will have it made into ricefields...; but will the authorities allow it? Won't that mean that the prestige will feel slapped on the face all ashamed, whereas isn't shamefulness the bitterest suffering for the Eastern people?

Dilemma, Pertiwi always lives in dilemmas, but Iin is young then, now already over middle age, will it be like this all the time, becoming Durga in Setragandamayit .... Ah, mystery of goodness! Mystery of evils! (Mangunwijaya, 1994: 182-183).

The love of Setadewa to Larasati, and vice versa, actually never dies (Burung-burung Manyar). But, they cannot be united in a marriage tie since Iin is married and has three children. When Iin and her husband, Janakatamsi, are killed in the Haj plane crash, Setadewa is determined 
to take care of the three children. He feels obliged to educate them well; they are the children of his former fiancée, he feels as if they were his own children. He defeats his own ego. Isn't this a nobel and sublime value? This value is a hypogram to the figure Baladewa in Mahabarata. After the war, Baladewa, who has become a monk, guards and educates Parikesit, grandson of Arjuna and is still a small child, so that in time he can become a good king of Astina.

Yeah, truly the heart of a widower very often feels lonely empty alone. But fortunately God the Omnigenerous still is willing to grant coolness for the day and night of my life path, by the agreement of the family and on the request of the father of Jana (not long after the Kolombo accident, he returned to the House of the Lord), the three children of Atik I adopted them as my children. The most beautiful gift from Atik and her husband whom I will guard and deliver to their future that complies with their identities and with the purist image language. Eventually, they truly have to work out their future by themselves, in order with their life calls. I just want to give them the most beautiful provision memories. Nothing more. (Mangunwijaya, 2014 (1981): 404).

The three novels also present values of the struggles to defend truths both of the male and female characters. The female fighters are Larasati (Burung-burung Manyar) and Iin (Durga Umayi) both in helping in the independence wars. The two characters clearly are hypograms to the figure Sri Kandi (Mahabarata) who is commonly adopted as a cultural referent as a female patriot in the Indonesian cultures. The figures Kumbakarna and his younger brother Wibisana (Ramayana) both refuse to help their older brother, Rahwana, the evil king (Anak Bajang Menggiring Angin). Kumbakarna eventually really goes to fight in the war, but with the intention to defend his country, not his brother. Wibisana chooses to side with the enemy (Rama) who is rightly believed as the good side. As stated by Sutrisno (2010: 6), through the wayang characters, wayang stories present a model, "model of" and "model for" man's choices in their life. Culture can become the source of good and bad evaluation system, whether it is valuabe or not (Sugiarti \& Putra, 2019) and wayang stories -with all the form of transformation- are a part of culture.

\section{CONCLUSION}

The study comes up with the following conclusion. Various aspects of wayang stories are adopted as comparison, signification, symbolization, cultural references, and even sources of writing in the three novels. The referencing to to the characterization in the wayang stories includes the naming and characterizing seen in three models. In the first model, the adoption of the names and characters is complete as it is (Anak Bajang Menggiring Angin and Durga Umayi); in the second, the naming and characterizing are simultaneous (Burung-burung Manyar); and in the third, the hypogramming is done to the characterizing with no naming (Durga Umayi). These facts show that wayang traditions 
are still strongly rooted in the society ( $\mathrm{Ja}$ vanese) and in modern Indonesian interature. The sociocultural backgrounds of the writers (especially Mangunwijata and Sindhunata) in many ways give the preconditions of the writing of the literary works. As heirs of the collective cultures, the writers feel the obligation to use means known widely by the public. The referencing to wayang stories shortens the narration (for the writer) and, on the other side, speeds up comprehension (for the readers) making communication happens more efficiently.

On the other side, the novel plots that are hypogrammed to the wayang plots include two paterns, wayang show plots and wayang story plots. pertunjukan wayang dan plot cerita wayang. The wayang show, that is performed in three time parts each having a typical story and music accompaniment, is hypogrammed in the novel Burung-burung Manyar that narrates the main characters also in three time phases of their life. Plot hypogramming to various wayang stories is found in the three novels, the most intensively being in Anak Bajang Menggiring Angin qand Burung-burung Manyar. Every work has its own uniqueness; and it is there that the values of a fiction work lie. This can be seen in the specific and unique development of the characterization and plot of the stories. In substance, wayang values are related to personal, social, and religious matters in the efforts to reach perfect life. The values are transmitted through comparison, signification, symbolization, characters, attitudes, and behaviours of the figures functioning as cultural references as can be seen in the three novels.

\section{REFERENCES}

Dwiyanto, Dj., Susantika, S., Widyawati, W. (2010). Ensiklopedi Wayang. Jogjakarta: Media Abadi.

Downes, M. (2012). Shadow on the Page: Javanese Wayang in Contemporary Indonesian Literarture. RIMA: Review of Indonesian and Malaysian Affairs, 46(1). (http://connection.ebscohost.com/c/articles/92582084/ shadows-page-javanese-wayang-contemporary-indonesian-literature).

Figuueras-Lucero, A.A. (1997). The Wayang Kulit the Narrative Framework of Pramudya Ananta Tur's Perburuan, Journal of English Studies and Comparative Literature, 2(1), 19-34. http://journals.upd.edu.ph/index. php/jescl/article/download/2479/2345.

Foley, K. (2005). Wayang and Gamelan as a Tool of Cultural Leaning: Indonesian Wayangs, Dance, and Music in the Classroom. Journal for Learning through the Arts, 1(1), 79-88. http: / / escholarship.org/uc/ item/1pd7d6ss\#page-1.

Groenendael, V.M.C. (1985). The Dalang behind the Wayang: The Role of the Surakarta and Yogyakarta Dalang in Indonesian-Javanese Society. Dordrecht: Foris.

Habib, M.A.R. (2005). A History of Modern Literay Criticism, from Plato to Present. Malden, Oxford: Blackwell Publishing.

Irwansyah, D., Nurgiyantoro, B., \& Sugirin. (2019). A Literature-Based Reading Instructional Model for Islam-Affiliated University in Indonesia, International Journal of Instruction, 12(3), 577-594. https://doi. 
org/10.29333/iji.2019.12335a.

Kasnowihardjo, H.G. (2012). Wayang Purwa: within a Study of Archaeology, Art, and Identity of a Nation. Paper was presented for the International Seminar for Sharing Art Ocean Mountain, Samudraraksa Ship Museum, Candi Borobudur, Central Java. http://www. academia.edu/3247508/Wayang_Purwa_A_Study_of_Archaeology_Art_and_Nation_Identity.

Kuntowijoyo. (1984). "Penokohan dan Perwatakan dalam Sastra Indonesia", dalam Andy Zoeltom (ed). Budaya Sastra. Jakarta: Rajawali, pp. 127-136.

Lal, P. (1992). Mahabrata. Jakarta: Pustaka Jaya (Penerjemah Hariadi S. Hartawardaya).

Lal, P. (1995). Ramayana. Jakarta: Pustaka Jaya (Penerjemah Djokolelono).

Mulyono, Sri. (1989). Wayang, Asal-usul, Filsafat, dan Masa Depannya. Jakarta: CV Haji Masagung.

Mustikasari, D., Andre, A. \& Nuriyah, L. (2012). Stories of Wayang Di Batas Angin by Yanusa Nugroho: Indonesia Wayang in Modern Literature. International Proceedings of Economics Development \& Research, 51, p.17. http://connection.ebscohost. $\mathrm{com} / \mathrm{c} /$ articles/87742914/storieswayang-di-batas-angin-by-yanusanugroho-indonesia-wayang-modern-literature).

O’Neill, M. (2017). Transformative Tales for Recessionary Times: Emma Donoghue 's Room and Marian Keyes' The Brightest Star in the Sky. Lit: Literature Interpretation Theory,
28(1), 55-74. http://tandfonline. c o m / d o i / f u 11/10.1080/10436928.2017.1275331

Padmosoekotjo, S. (1992). Silsilah Wayang Purwa Mawa Carita, jilid I-VII, Surabaya: Citra Jaya Murti.

Rajagopalachari, C. (2008). Mahabharata, Yogyakarta: IRCiSod.

Riffaterre, M. (1980). Semiotic of Poetry. London: Metheun \& CoLtd.

Rochmat, S. (2018). Transformative Education as a Dialectic of Indonesian Culture and Modern Culture, Cakrawala Pendidikan, 37(3), 366377. https://journal.uny.ac.id/index.php/cp/article/view/21513.

Sucipto, M. (2010). Ensiklopedi Tokoh-tokoh Wayang dan Silsilahnya. Yogyakarta: Narasi.

Sudjarwo, H.S., Sumari, \& Wiyono, U. (2010). Rupa \& Karakter Wayang Purwa. Jakarta: Kakilangit Kencana Prenada Media Group.

Sugiarti \& Putra, C.R.W. (2019). Representation of Culture Ecology in Wisran Hadi's Persiden, Litera, Jurnal Penelitian Bahasa, Sastra, dan Pengajarannya, 18(1), 17-35. https://journal.uny.ac.id/index.php/litera/article/view/20579.

Sunardi, DM. (1994). Ramayana. Jakarta: Balai Pustaka.

Sutrisno, M. (2010). "Sukma di Balik Wayang", "Pengantar" untuk Sudjarwo dkk, Rupa \& Karakter Wayang Purwa. Jakarta: Kaki Langit Kencana Prenada Media Group, pp.6-9.

Suwandono, Dhaniswara, \& Mujiyono. (1993). Ensiklopedi Wayang Purwa. Jakarta: Balai Pustaka.

Thomsen, M.R. (2017). "Changing Spaces: Canonization of Anglophone 
World Literature". Anglia, Journal of English Philology, 135(1), 51-66. https: / / www.degruyter.com / view/j/angl.2017.135.issue-1/ang2017-0004/ang-2017-0004. $\mathrm{xml}$ ?format $=\mathrm{INT}$.

Wibisono, S. (2009). Wayang, Karya Agung Dunia (http://www.SastraIndonesia.com/ 2009/12/Wayang, Karya Agung Dunia/).
Varela, M.E. (2014). Wayang Kontemporer: Innovations in Javanese Wayang. National University of Singapura: Dissertation, http://www.scholarbank.nus.edu.sg/bitstream/handle/10635/119799/MiguelEscobar2014.pdf?sequence $=1$. 